\title{
Characterisation of nucleolar proteins as autoantigens using human autoimmune sera
}

\author{
J PFEIFLE ${ }^{1}$ F A ANDERER, ${ }^{1}$ AND M FRANKE ${ }^{2}$ \\ From the ${ }^{1}$ Friedrich-Miescher-Laboratorium der Max-Planck-Gesellschaft, Tübingen, and the ${ }^{2}$ Staatliches \\ Rheumakrankenhaus, Baden-Baden, Federal Republic of Germany
}

SUMmARY Sera from 271 patients with systemic rheumatic diseases were screened for antinucleolar antibodies using immunofluorescence. Antinucleolar antibodies were found in the sera of $73 \%$ of patients with progressive systemic sclerosis, $4 \%$ of patients positive for autoantibodies with rheumatoid arthritis, and $8 \%$ of patients with rheumatoid arthritis associated with sicca complex, but not in patients with systemic lupus erythematosus, Sjögren's syndrome, undifferentiated connective tissue disease, or in healthy donors. The antinucleolar sera $(n=20)$ were analysed by immunoblotting techniques. In four sera antibodies against nucleolar proteins with molecular weights of $35 \mathrm{kD}, 37 \mathrm{kD}, 69 \mathrm{kD}, 92-93 \mathrm{kD}$, and $93 \mathrm{kD}$ could be immunodetected. The nucleolar autoantigens were extractable from the nucleoli together with the preribosomal particle fraction and could be solubilised by ribonuclease (RNAse) treatment. Their presence in the nucleolus was sensitive to actinomycin $\mathrm{D}$ treatment of cells. The $37 \mathrm{kD}$ autoantigen could bes identified as nucleolar phosphoprotein B23.

Key words: human antinucleolar antibody, nucleolar autoantigens, systemic sclerosis, rheumatoid arthritis.

Antinuclear antibodies are a characteristic feature of certain autoimmune disorders. They are directed against a varied spectrum of target antigens, deoxyribonucleic acid (DNA), ribonucleic acid (RNA), histones, ribonucleoproteins, and other proteins. ${ }^{1-4}$ Autoantibodies reacting with nucleolar components were first reported by Beck $^{5}$ and were frequently found in sera from patients with progressive systemic sclerosis. ${ }^{6-10}$ Detailed information on the number and identity of nucleolar proteins involved is still lacking, however, and one of the first steps towards elucidation of the mechanism by which certain nucleolar components become autoimmunogenic may be the identification of the autoantigens. The present study is aimed at the characterisation of nucleolar proteins reacting with human antinucleolar autoimmune sera obtained from patients with various autoimmune diseases.

Accepted for publication 5 June 1986.

Correspondence to Dr J Pfeifle, Friedrich-Miescher-Laboratorium der Max-Planck-Gesellschaft, Tübingen, Federal Republic of Germany.

\section{Patients and methods}

PATIENTS

All patients $(n=271)$ were registered at the Staatliches Rheumakrankenhaus in Baden-Baden. The clinical diagnosis was based on generally accepted criteria: 11 cases with progressive systemic sclerosis (PSS) and 14 cases with systemic lupus erythematosus (SLE) according to the preliminary criteria given by Masi et al ${ }^{11}$ and Cohen et al, ${ }^{12} 178$ cases with rheumatoid arthritis (RA) according to criteria described by Ropes et al, ${ }^{13}$ and eight cases with Sjögren's syndrome (SS) as described by Manthorpe et al. ${ }^{14}$ The autoimmune sera of patients with RA were preselected for positive immunofluorescence of the nucleus or the cytoplasma of HeLa cells, or both. Patients $(n=48)$ with rheumatoid arthritis associated with sicca complex (RA+SS) showed the criteria of RA, of keratoconjunctivitis sicca, and of xerostomia. The diagnosis of undifferentiated connective tissue disease (UCTD) was used when the symptoms did not fully correspond to the criteria of diagnosis cited above $(n=12)$. 
CELLS

HeLa S3 cells and L1210 mouse leukaemia cells were obtained from Flow Laboratories (Bonn, FRG). Cell culture conditions were as previously described. ${ }^{15}$

\section{N U C LEOL I}

Nucleoli were isolated from L1210 and HeLa suspension cells. The conditions of isolation as described by Muramatsu and Onishi ${ }^{16}$ were slightly modified, using a higher concentration of $\mathrm{MgCl}_{2}$ in the first step $(5 \mathrm{mmol} / \mathrm{l})$ and in the sonication step $(2 \mathrm{mmol} / \mathrm{l})$. Protein determinations were performed according to the method of Peterson. ${ }^{17}$

\section{ELECTROPHORETIC PROCEDURES}

Sodium dodecyl sulphate (SDS)-gel electrophoresis and transfer to nitrocellulose sheets (Schleicher and Schuell BA 83) were carried out according to standard procedures. ${ }^{18} 19$

\section{IMMUNODETECTION OF ANTIGENS ON}

\section{NITROCELLULOSE}

After electrophoretic transfer of nucleolar proteins nitrocellulose strips were incubated in saturation buffer $(0.01 \mathrm{M}$ inorganic phosphate $(\mathrm{Pi}) / 0.14 \mathrm{M}$ $\mathrm{NaCl} \mathrm{pH} 7.2,0.5 \mathrm{mM}$ phenylmethanesulphonyl fluoride, $0.5 \%$ Tween $20,10 \%$ fetal calf serum) at room temperature. After 30 min incubation human sera diluted 1:100 with saturation buffer were added and the strips further incubated for two hours. The strips were washed several times with washing buffer (0.01 M Pi/0.14 M NaCl pH 7.2, 0.05\% Tween 20) and then incubated for two hours with either peroxidase conjugated rabbit IgG specific for human IgG $(\mathrm{H}+\mathrm{L})$ (Miles, Frankfurt, FRG) or ${ }^{125} \mathrm{I}$ labelled sheep IgG specific for human IgG $(\mathrm{H}+\mathrm{L})$ (Amersham Buchler) diluted 1:1000 with saturation buffer or with $0.5 \mu \mathrm{Ci}{ }^{125} \mathrm{I}$ labelled $\mathrm{IgG} / \mathrm{ml}$ saturation buffer respectively. The washing was carried out as before. The peroxidase reaction was developed as described previously. ${ }^{15}$ Autoradiography was performed using Kodak-X-Omat film with a Dupont Cronex Quanta III intensifying screen.

AFFINITY PURIFICATION OF

A UTOANTIBODIES

Affinity purification of autoantibodies was carried out essentially according to the outline given by Krohne et al. ${ }^{20}$

EN Z Y M ES

RNAse, DNAse I, and proteinase $\mathrm{K}$ were obtained from Boehringer (Mannheim, FRG).

I M M U N OF L UOR E S C E N C E

HeLa cells were seeded on sterile glass coverslips and processed for immunofluorescence after one day's incubation at $37^{\circ} \mathrm{C}$.

The cells were washed with $0 \cdot 01 \mathrm{M} \mathrm{Pi} / 0 \cdot 14 \mathrm{M}$ $\mathrm{NaCl}$ pH 7.2 (phosphate buffered saline, PBS), fixed in a solution of $4 \%$ formaldehyde in PBS for 10 min, and made permeable by treatment with methanol at room temperature for $10 \mathrm{~min}$. After thorough washing with PBS the cells were incubated with human autoimmune sera, diluted 1:100 with PBS, and kept at $37^{\circ} \mathrm{C}$ for $45 \mathrm{~min}$. Thereafter the cells were washed three times with PBS followed by incubation with fluorescein isothiocyanate conjugated rabbit antihuman IgG $(\mathrm{H}+\mathrm{L})$ (Miles, Frankfurt, FRG) diluted 1:30 with PBS.

For RNAse or DNAse I treatment the washed cells were made permeable with methanol at room temperature for $10 \mathrm{~min}$. After drying, the coverslips were incubated with RNAse and DNAse I $(50 \mu \mathrm{g} / \mathrm{ml}$ each) in $\mathrm{PBS} / 1 \mathrm{mM} \mathrm{MgCl} 2$ at $37^{\circ} \mathrm{C}$ for $30 \mathrm{~min}$. A control without enzyme was included. After thorough washing with PBS $(5 \times 5 \mathrm{~min})$ the cells were fixed with $4 \%$ formaldehyde in PBS at room temperature for 10 min followed by further thorough washing with PBS. Thereafter, the cells were incubated with human sera and processed as described above.

ISOLATION OF NUCLEOLAR PROTEIN B 23 The isolation of B23 was carried out according to the outlines given by Michalik et al. ${ }^{21}$

\section{Results}

SERA WITH ANTINUCLEOLAR SPECIFICITY Sera of patients $(n=271)$ with rheumatic diseases were screened for antinucleolar autoantibodies by indirect immunofluorescence using HeLa monolayer cells fixed with formaldehyde. Most autoimmune sera $(228 / 271)$ reacted with nuclear or cytoplasmic antigens, or both. Under the given condition 33/48 RA+SS, 4/8 SS, 2/14 SLE, and 4/12 UCTD autoimmune sera were negative in the immunofluorescence test. Autoantibodies against nucleolar components were detected in 20/228 autoimmune sera. Only two of the 20 antinucleolar sera, however, showed a pure nucleolar staining in the immunofluorescence assay. The correlation of antinucleolar antibodies with a distinct diagnosis was as follows: progressive systemic sclerosis (PSS) $8 / 11(73 \%)$, rheumatoid arthritis associated with sicca complex (RA+SS) 4/48 (8\%), autoantibody positive rheumatoid arthritis (RA) 8/178 (4\%), Sjögren's syndrome (SS) $0 / 8$, systemic lupus erythematosus (SLE) 0/14, undifferentiated connective tissue disease (UCTD) 0/12, and healthy donors $0 / 21$. 


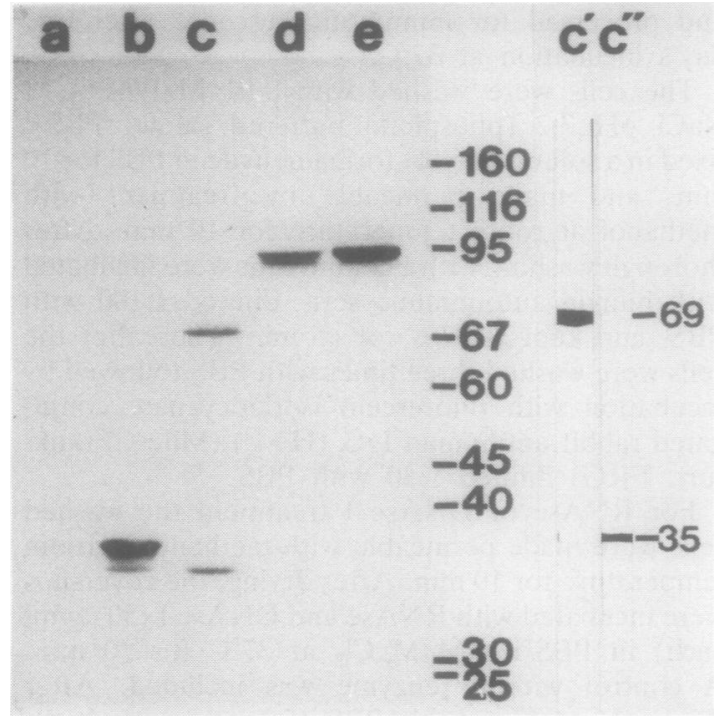

Fig. 1 Immunodetection of nucleolar components (HeLa S3) after SDS-gel electrophoresis and electrophoretic transfer to nitrocellulose. (a) Normal human serum as a control; (b) serum No I; (c) serum No 2; (d) serum No 3; (e) serum No 4; $\left(c^{\prime}, c^{\prime \prime}\right)$ Immunodetection by affinity purified antibodies derived from serum No 2 specific for $\left(c^{\prime}\right)$ $69 k D$ and $\left(c^{\prime \prime}\right) 35 k D$ components performed in separate experiments. The apparent molecular masses of protein standards are given in kilodaltons.

\section{IMMUNOBLOTTING WITH ANTINUCLEOLAR} S E R A

In order to identify individual nucleolar autoantigens only the 20 antinucleolar autoimmune sera selected by immunofluorescence were further characterised by immunoblotting experiments. The individual components of isolated $\mathrm{HeLa}$ S3 nucleoli were separated by SDS-gel electrophoresis and transferred to nitrocellulose sheets. Distinct immunoreactive nucleolar components could be detected only with $4 / 20$ sera.

The immunoreactive components had molecular weights of $35 \mathrm{kD}$ and $37 \mathrm{kD}$ reacting with serum No 1 (RA+SS, Fig. 1b), $35 \mathrm{kD}$ and $69 \mathrm{kD}$ reacting with serum No 2 (PSS, Fig. 1c), 92-93 kD reacting with serum No 3 (RA + SS, Fig. 1d), and 93 kD reacting with serum No 4 (RA, Fig. 1e). The non-identity of the $93 \mathrm{kD}$ component reacting with serum No 4 and the $93 \mathrm{kD}$ component of the double band resulting from the reaction with serum No 3 (Fig. 1d) was indicated by the differences in the immunofluorescence pattern obtained after treatment of HeLa cells with actinomycin D (Figs $3 g$ and $h$ ).
A F F I N ITY PUR I F I C A T ION OF

A UTOANTIBODIES

Monospecific autoantibodies are required for immunolocalisation of individual nucleolar components by the immunofluorescence assay since auto- $\bar{c}$ antibodies present against other components might $\frac{\bar{O}}{\overline{0}}$ interfere with the immunofluorescence pattern of a $\frac{\vec{\phi}}{\vec{\phi}}$ distinct component. Affinity purification of mono- $\varrho$ specific autoantibodies was performed with nitrocellulose strips carrying the individual autoantigens. $\vec{\circ}$ These were cut out from nitrocellulose sheets after Western transfer of nucleoli separated by SDS-gel $\vec{\omega}$ electrophoresis.

The affinity purified antibodies were used in immunofluorescence studies to confirm the nucleo- $f$ lar localisation of corresponding autoantigens.

A comparison of the fluorescence patterns obtained with the autoimmune sera and the pattern obtained with affinity purified antibodies is shown in 0 Fig. 2. The affinity purified antibodies showed an almost exclusively bright nucleolar fluorescence $\vec{\nabla}$ (Figs 2e-i). Interfering fluorescence of the nucleus and the cytoplasma disappeared from the sera as $\frac{\mathscr{}}{3}$ shown in Figs $2 \mathrm{a}$ and $\mathrm{e}$ and Figs $2 \mathrm{~d}$ and $\mathrm{i}$. In addition, the affinity purified antibodies were also used to decide whether the $35 \mathrm{kD}$ and $37 \mathrm{~kg} \overrightarrow{0}$ components (serum No 1) or the $35 \mathrm{kD}$ and $69 \mathrm{~km} \%$ components (serum No 2) showed any cross react ity. The nucleolar components $35 \mathrm{kD}$ and $37 \mathrm{kD}$ immunoreactive with serum No 1 (Fig. 1b) showed strong cross reactivity, indicating that the $35 \mathrm{kD}$ component may be a degradation product of the $\mathbb{D}$ $37 \mathrm{kD}$ component since the $35 \mathrm{kD}$ affinity purified antibody also reacted with the $37 \mathrm{kD}$ component and the $37 \mathrm{kD}$ affinity purified antibody with the $35 \mathrm{kD}$ component in the immunoblotting experiment. The components 35 and $69 \mathrm{kD}$ immunoreactive with serum No 2, however, did not show any cross reactivity in the immunoblotting experiment after $\overline{0}$ affinity purification (Figs $1 \mathrm{c}^{\prime}$ and $\mathrm{c}^{\prime \prime}$ ) but yielded similar fluorescence patterns probably due to similar 8 distributions in the nucleoli. This $35 \mathrm{kD}$ component $₹$ (serum No 2) showed no cross reaction with the 의 $35 \mathrm{kD} / 37 \mathrm{kD}$ components specified by serum No 1 . Affinity purification of antibodies to only one of the two nucleolar components (92-93 kD) immunoreactive with serum No 3 could not be achieved because ? of the small distance between the components $N$ separated by SDS-gel electrophoresis. Cross reactiv- N ity of these two components, therefore, cannot be excluded.

ENZYME SENSITIVITY OF AUTOANTIGENS The chemical nature of autoantigens was established? by treatment with various enzymes. Isolated nuc- $\frac{T}{0}$ leoli were treated with DNAse I $(1.7 \mathrm{mg} / \mathrm{ml})$, 

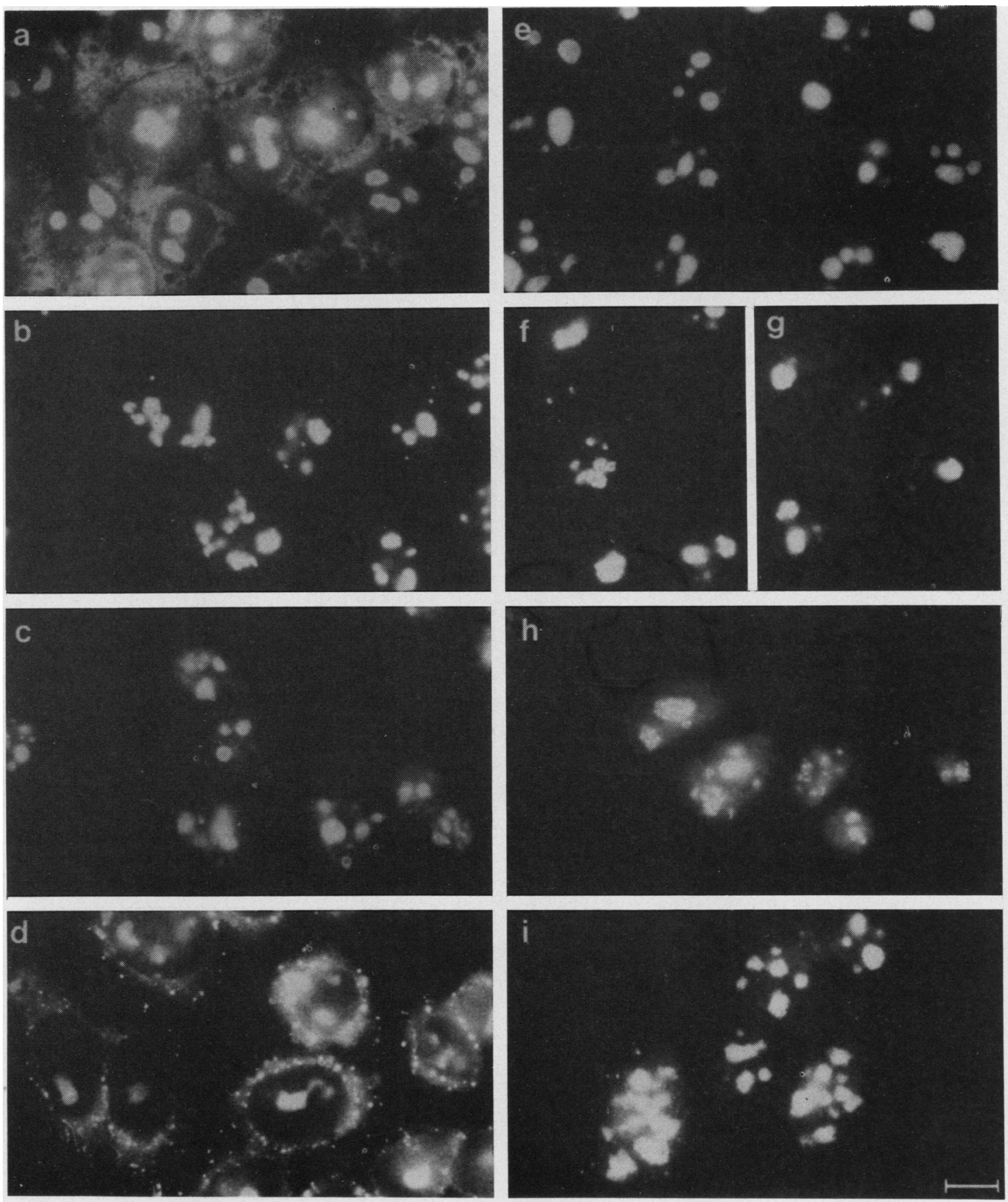

Fig. 2 Immunofluorescence patterns obtained in HeLa S3 monolayer cells with the antinucleolar autoimmune sera. (a) Serum No 1; (b) serum No 2; (c) serum No 3; (d) serum No 4; and with the corresponding affinity purified antibodies against the nucleolar components (e) $37 \mathrm{kD}$ serum No 1; (f) $69 \mathrm{kD}$ serum No 2; (g) $35 \mathrm{kD}$ serum No 2; (h) 92-93 kD serum No 3; and (i) $93 \mathrm{kD}$ serum No 4. Bar represents $10 \mu \mathrm{m}$. 
982 Pfeifle, Anderer, Franke
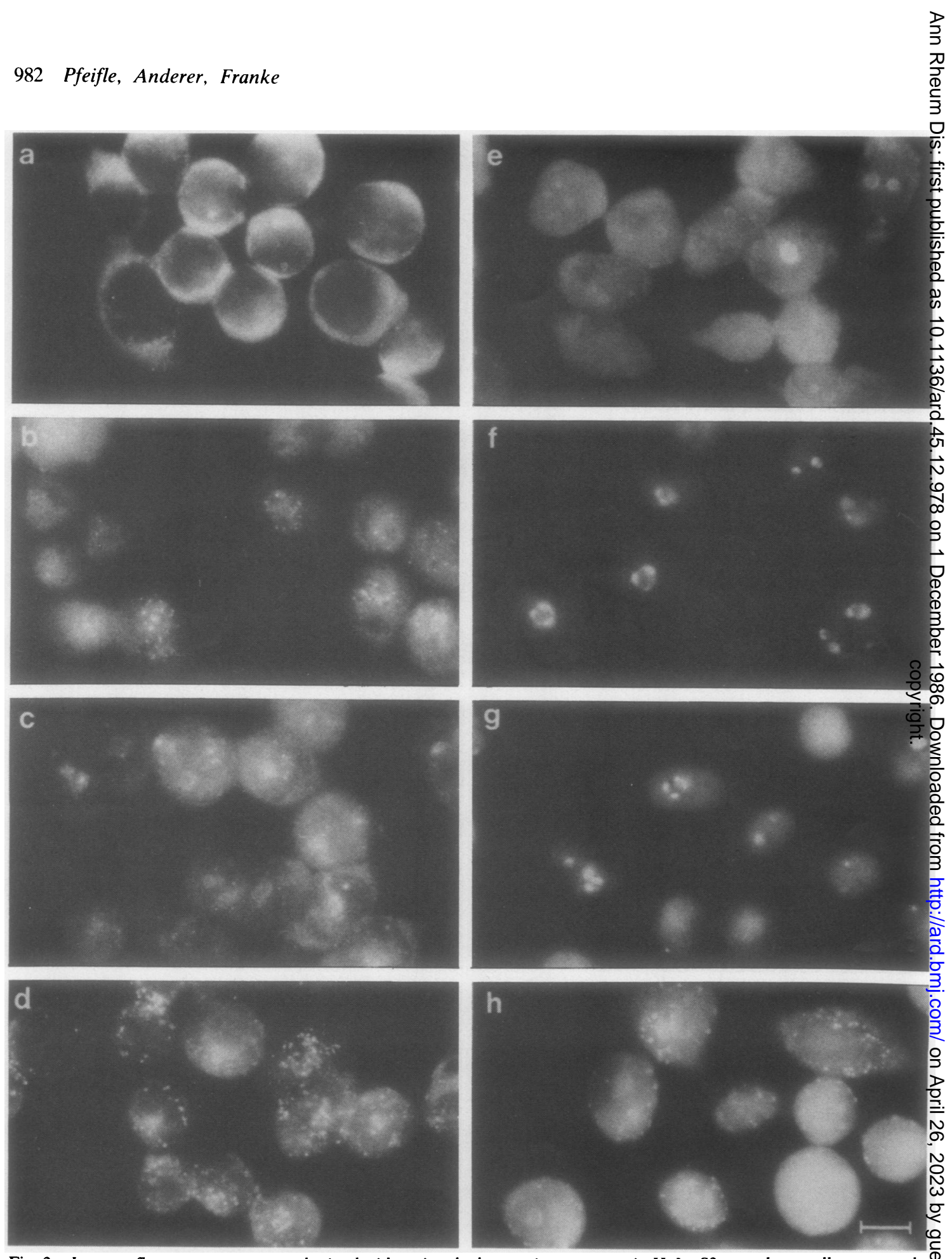

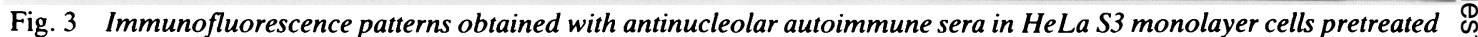
with (a-d) RNAse or preincubated with (e-h) actinomycin D. (a, e) Serum No 1; $(b, f)$ serum No 2; $(c, g)$ serum No 3; and : $(d, h)$ serum No 4. Bar represents $10 \mu \mathrm{m}$. 
RNAse $(1.7 \mathrm{mg} / \mathrm{ml})$, or proteinase $\mathrm{K}(1.7 \mathrm{mg} / \mathrm{ml})$ for $30 \mathrm{~min}$ at $37^{\circ} \mathrm{C}$. After gel electrophoresis and Western transfer of digested nucleolar components only the nucleoli treated with proteinase $\mathrm{K}$ lost their immunoreactivity with the autoimmune sera, indicating that the components recognised by these four sera are proteins. The association of the protein autoantigens with subnucleolar structures containing nucleic acids was investigated with similar techniques using immunofluorescence: HeLa monolayer cells were made permeable with methanol, dried and treated with RNAse $(50 \mu \mathrm{g} / \mathrm{ml})$ or DNAse I $(50 \mu \mathrm{g} / \mathrm{ml})$ for $30 \mathrm{~min}$ at $37^{\circ} \mathrm{C}$. Non-treated controls were included. After washing and fixation the cells were used for indirect immunofluorescence with the antinucleolar sera Nos 1-4. In all samples the nucleolar fluorescence was almost completely lost after RNAse treatment (Figs 3a-d). Controls without RNAse treatment or cells treated with DNAse I showed the bright nucleolar staining as in Figs $2 a-d$, indicating that all nucleolar autoantigens shown in Fig. 1 are associated with RNA fibrils.

\section{ACTINOMYCIN D TREATMENT}

In order to obtain information on the association of the identified nucleolar autoantigens with potential nucleolar functions we used pretreatment of cells with actinomycin D which stops elongation of ribosomal transcripts. We exposed HeLa monolayer cells on slides to $1 \mu \mathrm{g} / \mathrm{ml}$ actinomycin D for three hours before processing the slides for immunofluorescence. Nucleoli appeared intact in phase contrast after this treatment. All four antinucleolar sera (Nos 1-4) showed a different fluorescence pattern. The nucleolar protein autoantigens were now localised at the periphery of the nucleoli or were diffusely distributed over the whole nucleus. The central parts of the nucleoli were free of nucleolar autoantigens (Figs $3 \mathrm{e}-\mathrm{h}$ ). We concluded from these results that the nucleolar autoantigens were either directly or indirectly associated with components of the ribosomal transcription units and were released upon transcription arrest.

AUTOANTIGENSIN NUCLEOLAR

S U B F R A C T IONS

For the localisation of the nucleolar autoantigens in nucleolar subfractions HeLa cell nucleoli were subsequently extracted as described by Rothblum et al. ${ }^{22}$ This procedure yielded a $\mathrm{NaCl} /$ ethylenediaminetetra-acetate (EDTA) fraction (Fig. 4a), a $10 \mathrm{mM}$ TRIS (trometamol) fraction containing the preribosomal particles (Figs $4 \mathrm{~b}$ and c) which could be subdivided into a supernatant (Fig. 4b) and a $100000 \mathrm{~g}$ pellet (Fig. 4c), and the fraction of nucleolar chromatin (Fig. 4d). This procedure did not yield a clear cut separation of nucleolar subfractions, but it was useful for obtaining preliminary information. The nucleolar subfractions were characterised by SDS-gel electrophoresis and immunoblotting using the autoimmune sera Nos 1-4 (Figs 4I-IV). All identified nucleolar autoantigens were extractable with the $10 \mathrm{mM}$ TRIS fraction. The $10 \mathrm{mM}$ TRIS fraction was further separated into a pellet containing a preribosomal particle and a soluble supernatant by high speed centrifugation $(100000 \mathrm{~g}, 16 \mathrm{~h})$. The $69 \mathrm{kD}$ and $35 \mathrm{kD}$ proteins (Fig. 4II, serum No 2) and the $93 \mathrm{kD}$ protein (Fig. 4IV, serum No 4) were predominantly recovered in the

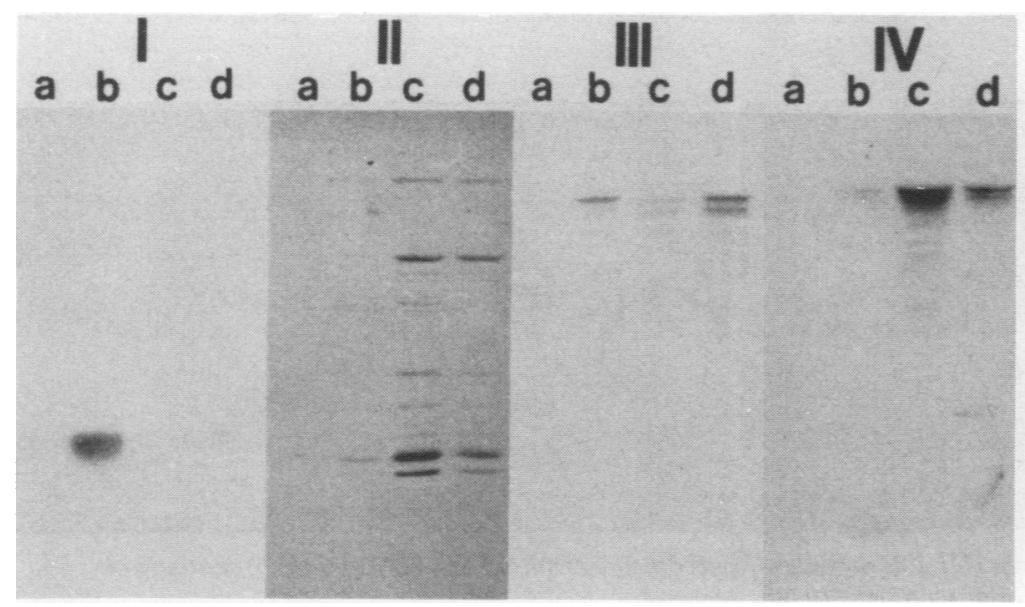

Fig. 4 Immunodetection of fractions obtained by sequential extraction of HeLa S3 nucleoli after SDS-gel electrophoresis and electrophoretic transfer to nitrocellulose using antinucleolar autoimmue sera. (I) serum No 1; (II) serum No 2; (III) serum No 3; and (IV) serum No 4. (a) Extraction with $\mathrm{NaCl}$ EDTA; (b) soluble supernatant and (c) pellet obtained by extraction with $10 \mathrm{mM}$ TRIS; (d) nucleolar chromatin. 


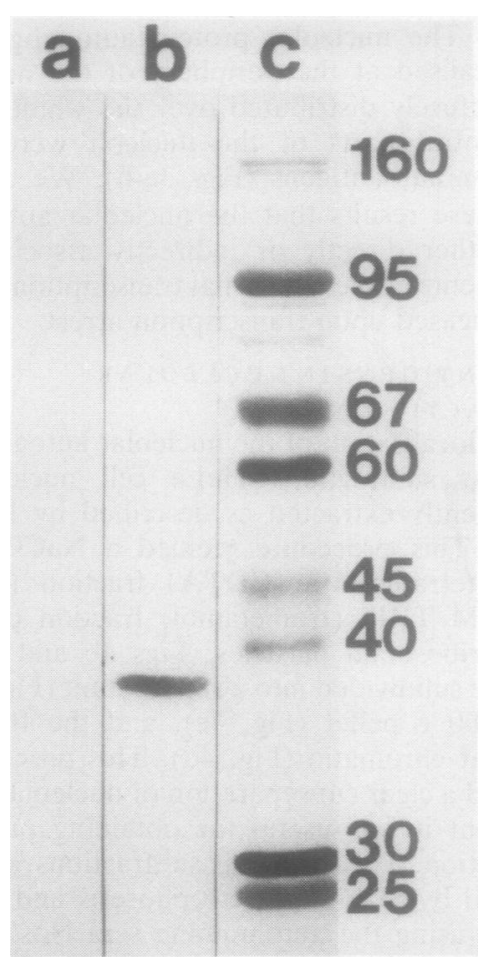

Fig. 5 Immunodetection of isolated nucleolar protein B23 after SDS-gel electrophoresis and electrophoretic transfer to nitrocellulose using (a) normal human serum; (b) antinucleolar autoimmune serum No I; and (c) molecular weight standards given in kilodaltons.

fraction containing the preribosomal particle (Fig. $4 c$ ), but smaller portions were still present in the fraction of nucleolar chromatin. The $37 \mathrm{kD}$ protein
(Fig. 4I, serum No 1) was exclusively found in the $10 \mathrm{mM}$ TRIS supernatant, whereas $92-93 \mathrm{kD}$ proteins (Fig. 4III, serum No 3 ) were predominantly detected in the $10 \mathrm{mM}$ TRIS supernatant and in the fraction of nucleolar chromatin, and to a lesser extent in the fraction containing the preribosomal particle.

CROSS REACTIVITY OF HUMAN AUTOIMMUNE SERA WITH MOUSE NUCLEOLAR ANTIGENS Interspecies cross reactivity was studied with the four autoimmune sera specified above using isolated mouse nucleoli. Antibodies to $35 \mathrm{kD}, 37 \mathrm{kD}, 92-$ $93 \mathrm{kD}$, and $93 \mathrm{kD}$ proteins showed strong cross reactivity with the corresponding mouse nucleolar of proteins of $36 \mathrm{kD}, 37 \mathrm{kD}, 92-93 \mathrm{kD}$, and $93 \mathrm{kD} \overrightarrow{\mathrm{N}}$ respectively, whereas antibodies to the $69 \mathrm{kD} 6$ protein cross reacted only slightly with the $\infty$ analogous mouse protein of $69 \mathrm{kD}$. 을

IDENTIFICATION OF THE $37 \mathrm{kD}$ ANTIGEN AS NUCLEOLAR PHOSPHOPROTEIN B 23

Comparison of the nucleolar autoantigens identified in this paper with nucleolar proteins described in the literature indicated a possible identity of the $37 \mathrm{kD}$ autoantigen with nucleolar phosphoprotein B23용 which also has a molecular weight of $37 \mathrm{kD}$. We isolated nucleolar phosphoprotein B23 as described by Michalik et al. ${ }^{21}$ The identity of both proteins was verified by gel electrophoresis and immunoblotting of isolated B23 (Fig. 5), by an enzyme linked immunosorbent assay with serum No 1 and by immunofluorescence studies (Fig. 6). After absorp- $\overline{\bar{O}}$ tion of serum No 1 with isolated B23 $(150 \mu \mathrm{g} / \mathrm{ml}$ serum) (Fig. 6b) the ability of staining nucleoli of HeLa cells was completely abolished.
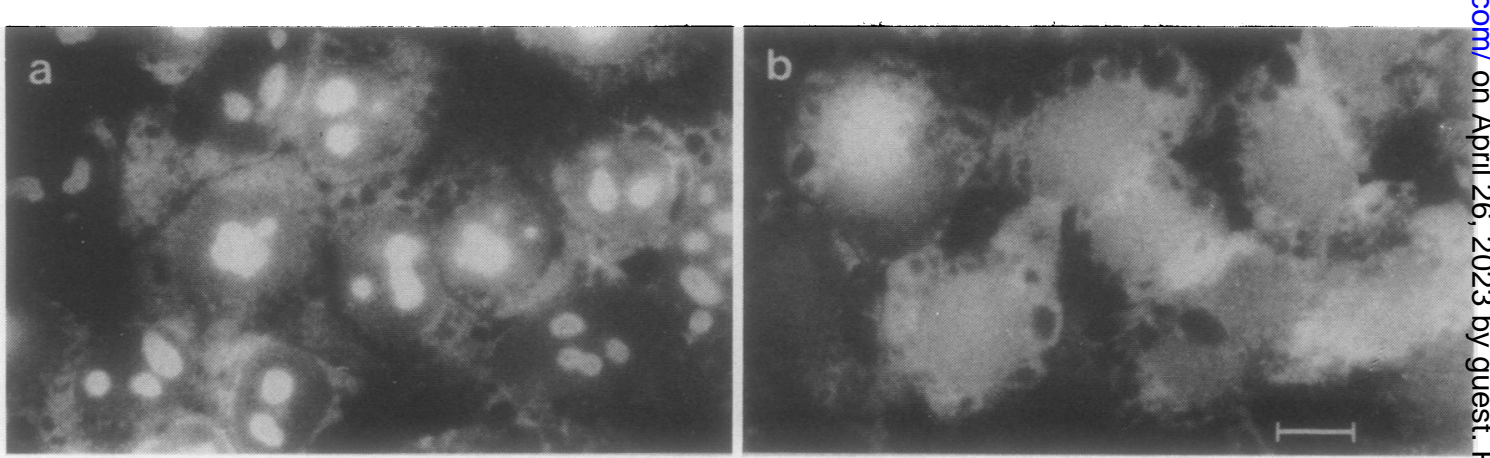

Fig. 6 Immunofluorescence patterns in HeLa S3 monolayer cells obtained with (a) serum No 1 and (b) serum No 1 absorbed with B23 (150 $\mu \mathrm{g} / \mathrm{ml}$ serum $)$. Bar represents $10 \mu \mathrm{m}$. 


\section{Discussion}

The investigations presented in this paper characterise at least five nucleolar autoantigens and identify one of them as nucleolar phosphoprotein B23.

All five autoantigens could be identified as proteins and were detected in the fraction containing the preribosomal particles of the nucleoli. The sensitivity of the nucleolar location of the five autoantigens to actinomycin D treatment of cells and the RNAse dependent solubility in situ lead us to the conclusion that the described autoantigens are components of the ribonucleoprotein or interact with the nucleolar ribonucleoprotein fibres.

In some earlier studies concerned with nucleolar autoantigens reacting with sera from patients suffering from rheumatic diseases a 4-6 S RNA was identified as the reacting component. ${ }^{9}$ Furthermore, ribonucleoprotein particles containing 7-5 S-A and 7-5 S-B RNA, ${ }^{23} 7-2$ S RNA, ${ }^{24} 25$ or U3 RNA ${ }^{25}$ have been described. Only one protein exclusively located in the nucleolus, RNA polymerase I, has been described so far to be immunoreactive with rheumatic autoimmune sera. ${ }^{26} \mathrm{We}$ are now able to identify the $37 \mathrm{kD}$ autoantigen as phosphoprotein B23, a major nucleolar protein. ${ }^{27}$ Further nucleolar autoantigens are represented by the $92-93 \mathrm{kD}$ (serum No 3 ) and $93 \mathrm{kD}$ (serum No 4) antigens, which appear not to be identical as seen by the differences in the immunofluorescence pattern obtained after treatment of HeLa cells with actinomycin D (Figs $3 g$ and $h$ ) and by their different distribution in the $10 \mathrm{mM}$ TRIS fractions of nucleoli (Figs 4III and IV). One of them, however, may be identical with a $94 \mathrm{kD}$ nucleolar protein also associated with ribonucleoprotein fibres. ${ }^{28}$ To our knowledge nucleolar proteins analogous to our $35 \mathrm{kD}$ and $69 \mathrm{kD}$ nucleolar autoantigens (serum No 2) have not yet been characterised. Our data concerning the corelation with clinical diagnosis and the frequency of expression of antinucleolar antibodies, which was especially high $(73 \%)$ in patients with PSS, are essentially in accordance with other reports. ${ }^{78}$ It is noteworthy that despite the fact that 8/11 autoimmune sera of patients with PSS showed positive nucleolar immunofluorescence only $1 / 11$ autoimmune sera reacted with nucleolar components after SDS-gel electrophoresis. This may be due to SDS sensitive epitopes or to epitopes present on RNA which do not bind to nitrocellulose under the conditions used. On the basis of these findings it is necessary to include other autoantigens, such as scl-70 and centromere, ${ }^{2}$ into molecular immunodiagnostics of PSS. The identified nucleolar autoantigens represent a promising basis for further investigations of the specific cellular functions of autoantigens, which might help to elucidate the aetiologies of autoimmune disease.

We thank S Himmer for excellent technical assistance.

\section{References}

1 Douvas A S. Tan E M. Human antibodies to RNA containing particles. In: Busch H. Rothblum L, eds. The cell nucleus. New York, London: Academic Press, 1981; 8: 369-87.

2 Tan E M. Autoantibodies to nuclear antigens (ANA): their immunobiology and medicine. Adv Immunol 1982; 33: 167-240.

3 Seelig H P. Antikörper gegen Zellkernantigene. Labormedizin und Klinik 1. Stuttgart. New York: Gustav Fischer, 1983.

4 McNeilage L I, Wittingham S. Mackay I R. Autoantibodies reactive with small ribonucleoprotein antigens: a convergence of molecular biology and clinical immunology. J Clin Lab Immunol 1984; 15: 1-17.

5 Beck I S. Variations in the morphological patterns of autoimmune' nuclear fluorescence. Lancet 1961; i: 1203-5.

6 Beck I S. Anderson I R. McEltrinney A I, Rowell N R. Antinucleolar antibodies. Lancet 1962: ii: 575-7.

7 Ritchie R F. Antinucleolar antibodies. Their frequency and diagnostic association. $N$ Engl J Med 1970; 282: 1174-8.

8 Miyawaki S, Ritchie R F. Nucleolar antigen specific for antinucleolar antibody in the sera of patients with systemic rheumatic disease. Arthritis Rheum 1973; 16: 727-36.

9 Pinnas I L. Northway I D. Tan E M. Antinucleolar antibodies in human sera. J Immunol 1973: 111: 996-1004.

10 Kenneally D. Mackay I R. Toh B H. Antinucleolar autoantibodies demonstrated by monolayers of human fibroblasts in sera from patients with systemic lupus erythematosus, progressive systemic sclerosis and chronic active hepatitis. J Clin Lab Immunol 1984: 14: 13-6.

11 Masi A T. Rodnau G P. Medsger T A. et al. Preliminary criteria for the classification of systemic sclerosis (scleroderma). Bull Rheum Dis 1981; 31: 1-6.

12 Cohen A S. Reynolds W E. Franklin E C. et al. Preliminary criteria for the classification of systemic lupus erythematosus. Bull Rheum Dis 1971; 21: 643-8.

13 Ropes M W. Bennett G A. Cobb S. Jacox R, Jessar R A. 1958 revision of diagnostic criteria for rheumatoid arthritis. Bull Rheum Dis 1958: 9: 175-6.

14 Manthorpe R. Frost-Larsen K. Isager H. Prause I U Sjögren's syndrome. Allergy 1981: 36: 139-53.

15 Pfeifle J. Anderer F A. Isolation and localization of phosphoprotein pp 135 in the nucleoli of various cell lines. Eur $J$ Biochem 1984; 139: 417-24.

16 Muramatsu M. Onishi T. Isolation and purification of nucleoli and nucleolar chromatin from mammalian cells. Methods Cell Biol 1978; 17: 141-61.

17 Peterson G L. A simplification of the protein assay method of Lowry et al which is more generally applicable. Anal Biochem 1977; 83: 346-56.

18 Laemmli U K. Cleavage of structural proteins during the assembly of the head of bacteriophage T4. Nature 1970; 227: 680-5.

19 Burnette W N. 'Western blotting': electrophoretic transfer of proteins from sodium dodecyl sulfate-polyacrylamide gels to unmodified nitrocellulose and radiographic detection with antibody and radioiodinated protein A. Anal Biochem 1981; 112: 195-203.

20 Krohne G. Stick R. Kleinschmidt I A. Moll R. Franke W W, Hausen P. Immunological localization of a major karyoskeletal protein in nucleoli of oocytes and somatic cells of Xenopus laevis. J Cell Biol 1982: 94: 749-54.

21 Michalik I. Yeoman L G. Busch H. Nucleolar localization of protein B23 (37/5.1) by immunocytochemical techniques. Life Sci 1981: 28: 1371-9. 
22 Rothblum L I. Mamrock P M. Kunkle H M. Olson M O I. Busch $H$. Fractionation of nucleoli. Enzymatic and twodimensional polyacrylamide gel electrophoretic analysis. Biochemistry 1977: 16: 4716-21.

23 Nakao Y. Mukai R. Kabashima T. et al. A novel antibody which precipitates 7-5 S RNA is isolated from a patient with autoimmune disease. Biochem Biophys Res Commun 1982; 109: $1332-8$.

24 Hashimoto C. Steitz I A. Sequential association of nucleolar 7-2 RNA with two different autoantigens. J Biol Chem 1983: 258: $1379-82$.

25 Reddy R, Tan E M. Henning D. Nohga K. Busch H. Detection of nucleolar 7-2 ribonucleoprotein and a cytoplasmic 8-2 ribonucleoprotein with autoantibodics from patients with scleroderma. J Biol Chem 1983: 258: 1383-6.

26 Stetler D A. Rose K M. Wenger M E. Berlin C M. Jacob S T Antibodies to distinct polypeptides of RNA polymerase $I$ in $\overline{\vec{n}}$ sera from patients with rheumatoid autoimmune discase. Proc Natl Acad Sci USA 1982: 79: 7499-503.

27 Spector D L. Ochs R L. Busch H. Silver staining. immunofluorescence. and immunoclectron microscopic localization of nucleolar phosphoprotein B23 and (23. (Chromosoma 1984: 90: $139-48$.

28 Kistler I. Duncombe Y. Laemmli U K. Mapping nucleolar ô proteins with monoclonal antibodics. J Cell Biol 1984: 99: $\overrightarrow{0}$ $1981-8$ 